\title{
Effects of Biotic and Abiotic Environmental Stimuli on the Morphology and Biomass Allocation of Mimosa pigra $\mathrm{L}$.
}

(Kesan Rangsangan Persekitaran Biotik dan Abiotik ke atas Morfologi dan Pengagihan Biojisim Mimosa pigra L.)

\author{
NUR-ZHAFARINA A.* \& ASYRAF M.
}

\begin{abstract}
The main focus of this study was to examine the morphology of Mimosa pigra, an invasive weed in response to artificial biotic and abiotic stressors. Seedlings of M. pigra were subjected to stressors such as seed sowing density, leaf defoliation and water regime. Comparatively, morphological performance related to different sowing practices differed significantly $(\mathrm{p}<0.05)$, as seedlings that grew from high density populations had lean and outstanding apical growth. A comparison between the four different levels of defoliation on the morphological changes revealed that the increase in leaf defoliation significantly decreased the plant morphological traits (i.e. height, stem diameter and flower bud productivity) and biomass allocation. Relatively low growth performance was found in plants subjected to $100 \%$ defoliation, with markedly lower flower bud productivity in comparison with 0\%, 25\% and 50\% (no flower buds compared to 27, 13 and 6 flower buds, respectively). For water stress treatment, M. pigra showed no significant difference ( $\mathrm{p}>0.05)$ in morphological performance under different levels of water regime. However, seedlings that received low water (LW) treatment showed better growth performance than seedlings that received high water $(\mathrm{HW})$ treatment, which had the lowest morphological traits and biomass allocation.
\end{abstract}

Keywords: Abiotic; biotic; environmental stressor; Mimosa pigra; morphological traits

\section{ABSTRAK}

Fokus utama penyelidikan ini adalah mengkaji tindak balas Mimosa pigra terhadap tekanan biotik dan abiotik tiruan. Anak benih M. pigra telah dikenakan tekanan kepadatan penyemaian benih, pemotongan daun dan rejim air. Secara perbandingan, prestasi morfologi bagi kesemua kepadatan yang berlainan menunjukkan perbezaan yang ketara $(\mathrm{p}<0.05)$ disebabkan anak benih yang tumbuh daripada kepadatan penyemaian benih tinggi mempunyai pertumbuhan atas yang kurus dan tinggi berbanding dengan anak benih daripada kepadatan yang lain. Perbandingan antara empat tahap pemotongan daun yang berbeza terhadap perubahan morfologi M. pigra menunjukkan bahawa peningkatan pemotongan daun secara ketara mengurangkan ciri morfologi (tinggi, diameter batang dan penghasilan kudup bunga) dan pengagihan biojisim. Prestasi pertumbuhan relatif yang rendah telah ditunjukkan oleh pokok yang dikenakan $100 \%$ pemotongan dengan penghasilan kudup bunga yang sangat rendah berbanding dengan 0\%, 25\% dan $50 \%$ pemotongan (tiada kudup bunga berbanding 27, 13 dan 6 kudup bunga). Bagi perlakuan tekanan air, tiada perbezaan morfologi yang ketara $(\mathrm{p}>0.05)$ ditunjukkan oleh $\mathrm{M}$. pigra yang telah dikenakan dengan pelbagai tahap tekanan air yang berbeza. Walau bagaimanapun, anak benih yang telah menerima perlakuan air rendah (LW) menunjukkan prestasi pertumbuhan yang lebih baik berbanding anak benih yang menerima perlakuan air tinggi $(\mathrm{HW})$ kerana mempunyai ciri morfologi dan pengagihan biojisim terendah.

Kata kunci: Abiotik; biotik; Mimosa pigra; sifat morfologi; tekanan persekitaran

\section{INTRODUCTION}

The most dominant weeds in the world are those that have been introduced to new habitats, sometimes accidentally, but all too often intentionally (Marko 1999; Myers \& Bazely 2003). Introduced weeds may show differences in growth performance, either natively or in a newly invaded locality (Sexton et al. 2002). As such, Mimosa pigra, an invasive woody weed, shows low pod production when in its native locale, in comparison with invaded areas in which a significant increase of pods production in one season has been observed (Lonsdale 1992). A natural environment presents many challenges to plants in their natural habitats, with exposure to various sources of advantageous and disadvantageous biotic and abiotic environmental stressors (Trewavas 2009). These stressors may not only lead to changes in plant morphology, but also indirectly alter the way plants respond and change their metabolic system in nature (Mandre 2002). In the early 19th century, M. pigra was known as an ornamental plant. Some consider $M$. pigra as a useful and beneficial agricultural plant and it was intentionally introduced to Thailand from Indonesia (Miller 2004). However, ever since its population explosion in the 1980s, M. pigra has become a serious threat to the biodiversity, water resources, economy and tourism of 
invaded countries (Beilfuss 2007; Lonsdale et al. 1988; Napompeth 1983). In many disturbed areas where M. pigra has recently invaded, the plant can grow profusely up to $6 \mathrm{~m}$ to form dense thickets, preventing access to these areas (Marko 1999). Studies have also suggested that $M$. pigra is able to outperform most other native species of grasses and forbs, reduce the diversity of native animals, interfere with the cultivation of economically important plants (palm oil and rice) and block access to pans and waterways (Orwa et al. 2009; Praneetvatakul 2001). In particular, M. pigra infestation scenario in Malaysia is persistent, especially within man-made disturbed areas (Asyraf \& Crawley 2011), although a significant impact on native flora and fauna has yet to be empirically quantified. Based on the stage of resilience, plants have different tolerance mechanisms and reactions, as well as responses to various sources of environmental stress and the subjected stress factor (Mandre 2002). Thus, this study focuses on $M$. pigra responses to artificial stress in terms of changes in morphological attributes and reproductive capability in order to gather specific information on plant resistance to biotic and abiotic environmental stresses. This study is significant, as those stressors will affect the plant establishment and also its subsequent development, including its reproductive capability. The objectives of this study were to evaluate the M.pigra responses towards several simulated biotic stressors (i.e. plant intraspecific competition and herbivory) and abiotic stressors (i.e. water regime) which may inhibit the plant development and reproduction. Findings from this research could contribute to a better management program to control and eradicate invasive plants in future.

\section{MATERIALS AND METHODS}

Matured $M$. pigra seeds used in this experiment were collected from the wild population in Penang, Kedah and Perak (Malaysia). Seeds were removed from ripe pods and stored in a dry container at room temperature for further usage. The seeds used in this experiment were partially scarified to trigger early germination.

\section{INTRASPECIFIC COMPETITION}

The experiment was conducted at an experimental plot in Universiti Sains Malaysia (5 ${ }^{\circ} 21.226^{\prime}$ N, $100^{\circ} 17.915^{\prime}$ E). The plot was designed with a four $1 \times 1 \mathrm{~m}$ split plot system. Each split plot was planted with $M$. pigra seeds sown at different densities: 78 seeds for low density (LD), 157 seeds for medium density (MD) and 314 seeds for high density (HD). The whole experiment was replicated three times in separate quadrats in the same plot area.

\section{LEAF DEFOLIATION AND FLOWER BUD PRODUCTION}

$M$. pigra seedlings were subjected to four defoliation treatments with ten sets of plants for each treatment as follows: $1.0 \%$ defoliation (control); 2. 25\% defoliation;
3. 50\% defoliation; and 4. 100\% defoliation. Treatments were applied when the seedlings reached the four-leaf stage (Yasari \& Golafshan 2012), as the related seedlings were successfully adapted to environmental conditions. Defoliation treatments were applied weekly and any newly borne leaflets at previously defoliated areas were removed. The growth performance (i.e. based on morphology) experiment was conducted for six weeks and the morphological traits of the treated plant were recorded. A flower bud production experiment was conducted over thirty-two weeks (eight months). The emergence of flower buds was documented at the end of the experiment.

\section{WATER STRESS}

Three watering regimes were carried out. Plants were watered with high water ( $\mathrm{HW})$, moderate water (MW) and low water (LW) volumes based on the rain gauge watering level: the watering volumes were $6.0,31.5$ and $65 \mathrm{~mm}$, respectively. The amount of water was determined based on the annual daily rainfall in Bayan Lepas, Penang, as recorded by the Malaysian Meteorological Department (2012). Treatments were conducted for six weeks and there were ten sets of plants for each treatment. Irrigation was performed once a day with no nutrients or pesticides applied to the soil (Manjeru et al. 2007). Water loss within the experimental plots was not encountered, as the experiment simulated later field conditions.

\section{MORPHOLOGICAL AND STATISTICAL ANALYSES}

All data regarding plant morphological traits (i.e. height, stem diameter and biomass) and flower bud production were recorded at the end of the experiment. The normally distributed data were analyzed using one-way ANOVA and the data that failed the transformation process were analyzed using the Kruskal-Wallis test via SPSS software. The correlation coefficient (r) was also determined to quantify the relationship between the levels of different stressors with the M. pigra morphological traits in a linear fashion.

\section{RESULTS AND DISCUSSION}

\section{EFFECT OF DIFFERENT SEED-SOWING DENSITIES}

Seedlings from LD had short sturdy stems with high diameter growth and plant biomass. In comparison, seedlings from the MD treatment showed average growth of stem height and girth, but had the highest above-ground and the lowest below-ground biomass, while seedlings from HD had the tallest and thinnest stem diameters with medium biomass performance (Figure 1). Comparatively, morphological performances related to different sowing practices differed significantly, with height $\left(\mathrm{F}_{3,76}=211.18\right.$, $p<0.05)$, stem diameter $\left(\mathrm{F}_{3,76}=593.36, p<0.05\right)$ and above-ground $\left(\mathrm{F}_{3,36}=226.05, p<0.05\right)$ and below-ground biomass $\left(\mathrm{F}_{3,36}=54.55, p<0.05\right)$. Different treatments in 


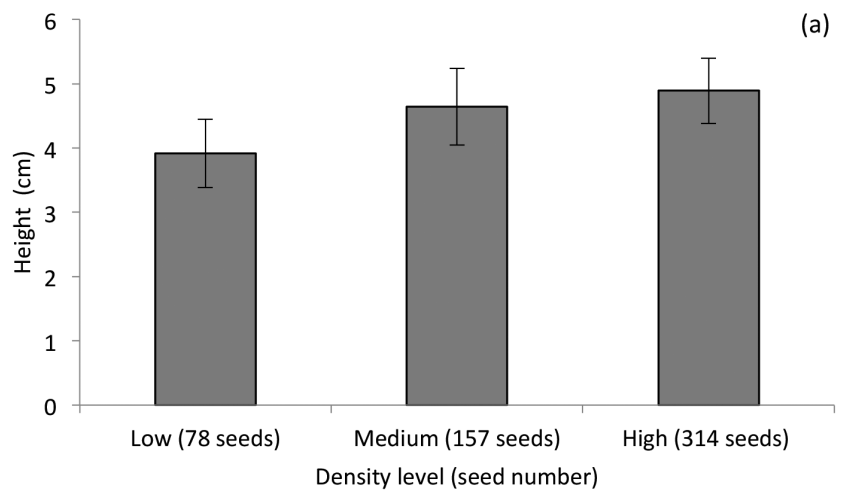

(a)
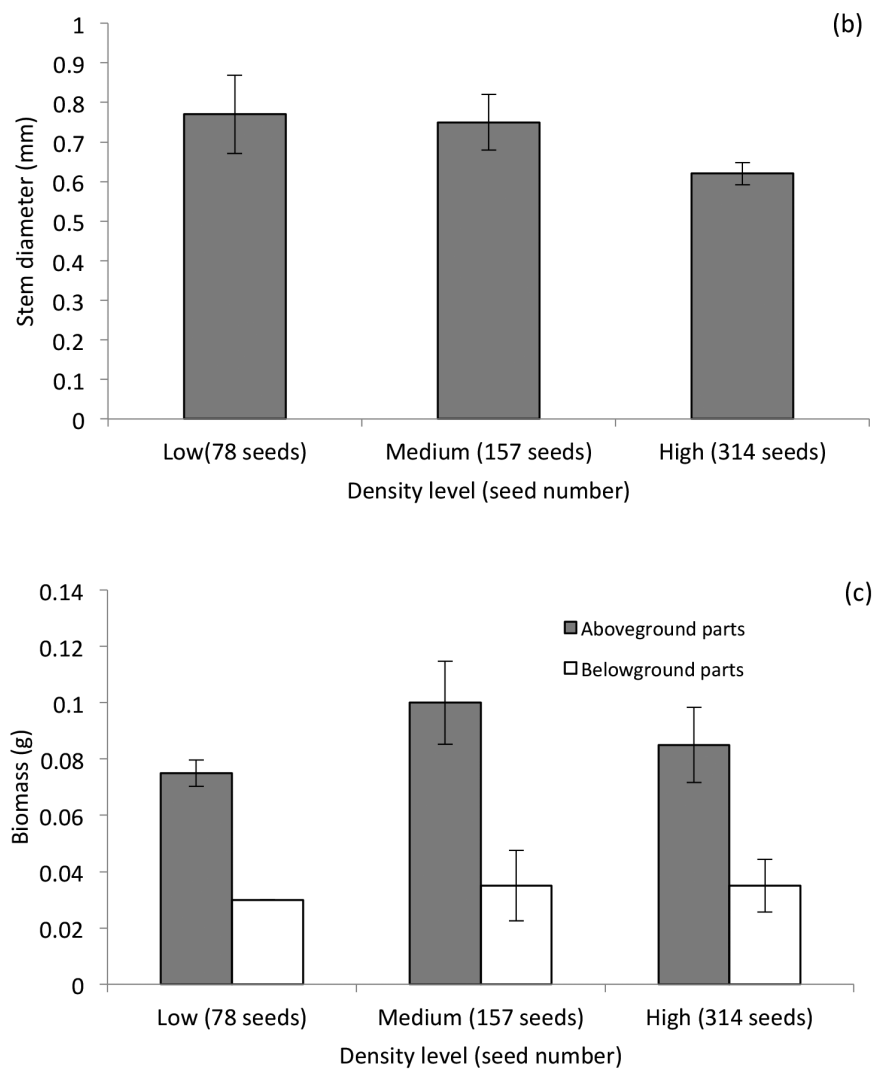

FIGURE 1. Morphological performances on (a) plant height and (b) stem diameter and (c) plant biomass of the survival seedlings grew from different sowing densities growth conditions

terms of density also had a strong correlation with the morphological traits, with height $(r=0.824, p<0.05)$, stem diameter $(r=-0.539, p<0.05)$ and biomass (above-ground: $r=0.822, p<0.05$ and below-ground: $r=0.859, p<0.05)$. The present findings suggested that $M$. pigra height increased with seedling density and these support the findings reported by Nagashima and Hikosaka (2011), indicating that height convergence increases with the increase of the shading canopy as well as in intensely competing plant communities. Plasticity enables $M$. pigra to increase resource uptake to improve survivability and this situation might arise quite commonly for competing plants such as weeds (Ballare et al. 1988). It is suggested that the ability to grow quickly in height is an important adaptation mechanism when plants are deprived of ample resources (Pires et al. 2012). The development of the stem diameter was inversely proportional to the plant height, and it is believed that height growth convergence was slowing down the stem development. This process has been explained thoroughly by Lambers et al. (2008). The development processes of plant primary growth (i.e. plant height) and secondary growth (i.e. stem diameter) occur concurrently. Primary meristem gives rise to stem and root length development, while lateral meristem highlights the growth in girth. However, when environmental conditions change, this alters the process, whereby either one process or the other will take control of the plant development. This further means that one aspect will grow vigorously while 
the other process will be slowed down. Despite the fact that the differences in total biomass between MD and HD, seedling rates were not significant and it may be concluded in sum that high density competition resulted in increased total plant biomass. The biomass of the above-ground $M$. pigra parts was also quantified to be higher compared with the below-ground parts, supporting the findings of Keddy (1990), in which the competitive effect on perennial plants resulted in the accumulation of above-ground biomass.

\section{EFFECT OF DIFFERENT DEFOLIATION INTENSITIES ON MORPHOLOGY AND FLOWER BUD PRODUCTION}

Plants subjected to $0 \%$ defoliation exhibited the highest growth, followed by those with $25 \%, 50 \%$ and $100 \%$ defoliation (Figure 2(a)). However, the statistical analysis showed that there was no significant effect of defoliation practices on the plant height of the four variables $\left(\mathrm{F}_{3,24}=\right.$ $2.945, p>0.05)$. Furthermore, no correlation was found $(r=-0.449, p>0.05)$ between defoliation treatments and plant height. There was a significant difference of $\chi^{2}$ (3, $\underline{\mathrm{N}}=28)=9.168, p<0.05$ of stem diameter across the four defoliation practices, in which $0 \%$ defoliation illustrated the highest diameter growth, followed by $25 \%, 50 \%$ and $100 \%$ defoliation intensities (Figure 2(b)). However, it was hypothesized that a weak negative relationship existed between defoliation and stem diameter $(r=-0.513$, $p>0.05)$. There was a significant difference $\left(\mathrm{F}_{2,25}=40.668\right.$, $p<0.05)$ in the effect of defoliation intensities on flower bud production across the treatments. Relatively, plants subjected to $0 \%$ defoliation had the highest total flower bud production, followed by $25 \%$ and $50 \%$ defoliation. As predicted, the plants subjected to $100 \%$ defoliation failed to produce any flower buds (Figure 2(c)). Furthermore, a strong negative correlation was found between the treatments and flower bud productivity $(r=-0.875$, $p<0.05)$. Based on Figure 2(d), $0 \%$ defoliation showed the highest in total above- and below-ground biomass, followed by $25 \%, 50 \%$ and $100 \%$ defoliation. There were significant differences in above- and below-ground biomass across the four defoliation intensities $\left(\chi^{2}(3, \underline{N}=28)=15.784, p<0.05\right.$ and $\chi^{2}(3, \underline{\mathrm{N}}=28)=13.532, p<0.05$, respectively $)$. Overall, both variables were strongly correlated (above-ground; $r$ $=-0.865, p<0.05$ and below-ground; $r=-0.766, p<0.05$, respectively).

A strong relationship was demonstrated between $M$. pigra height, stem diameter, plant biomass and flower bud production. The severity of the simulation defoliation treatment at the early growth stage of $M$. pigra seedlings negatively affected the subsequent performance of the growth. This has been positively shown in many studies which have emphasized that a decrease in one plant part could affect the whole growth performance in plant development (Baraza et al. 2007; Koptur et al. 1996; Striker et al. 2008). The results of this experiment suggested that M.pigra metabolism continually decreased with the time of development and with subsequent treatment. A related study by Quintero and Bowers (2013) suggested that the severity of damage that occurred in the seedling development limits the availability of storage of resources and resource acquisition. Moreover, the damage may have a consistent and long-term impact on plant growth as well as the production capability of the plants themselves as a result of aberrant metabolism (Hanley \& Fegan 2007; Orcutt \& Nilsen 2000). Defoliated M. pigra could either thrive throughout the development process or be defeated in the middle of development, depending on how well metabolism and resources are allocated within plants. Repetition of the total removal of leaves (100\% defoliation) in the early $M$. pigra growth had a detrimental effect on plant performance, as the practice successfully suppressed, constrained and decreased plant growth, as well as flower bud production, similarly to the outcomes shown in studies
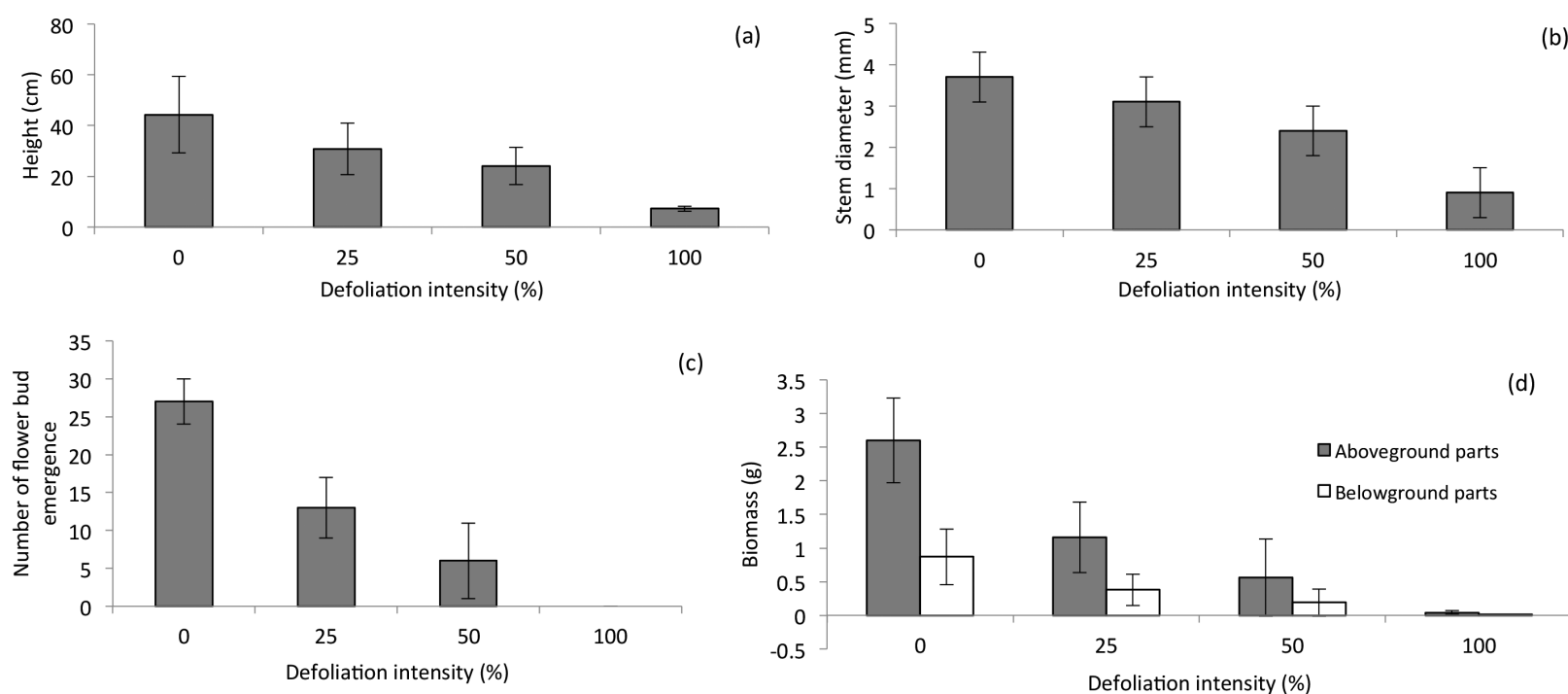

(c)

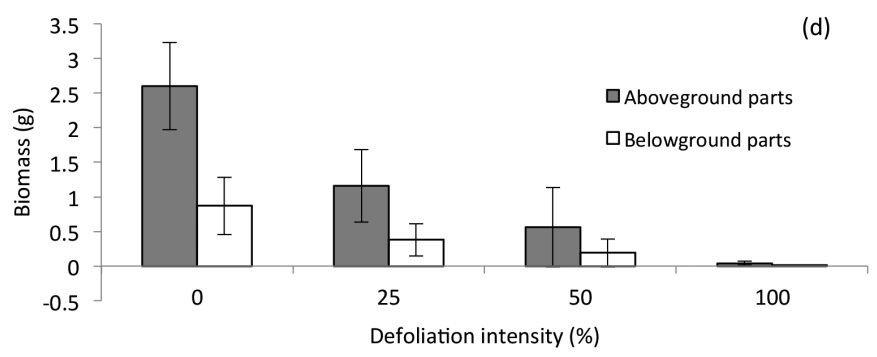

FIGURE 2. Morphological performances on (a) height, (b) stem diameter, (c) flower bud production and

(d) Plant biomass of different defoliation intensities of $M$. pigra leaves 
on legumes (Koptur et al. 1996; Richards 1993). This study further suggests that plants can only compensate for losses at low levels of damage (i.e. $25 \%$ and $50 \%$ ), with partial replacement of lost tissue through the ability to continue growth and flower bud production. The results of this study were similar to the findings of Wirf (2006), in which the defoliated M. pigra plants were able to maintain their fitness other than having lower growth capacity (i.e. due to the lost plant parts) compared to non-defoliated plants ( $0 \%$ defoliation). The plant itself has an ability to thrive in conditions where it is exposed to levels which are lethal to other species or populations (Fitter \& Hay 2002).

\section{EFFECT OF WATER STRESS ON MORPHOLOGICAL PERFORMANCES}

Plants from the LW treatment demonstrated the highest rate of growth in height, followed by $\mathrm{MW}$, and plants from the HW treatment achieved the lowest height compared to other treatments (Figure 3(a)). There were no significant effects $\left(\mathrm{F}_{2,18}=2.631, p>0.05\right)$ of different water volumes received by plants on plant height across the levels of treatment. As for the stem diameter, the increase in water volume decreased plant stem diameter, such that plants from the MW treatment group had the highest diameter growth relative to other treatments. Meanwhile, plants that
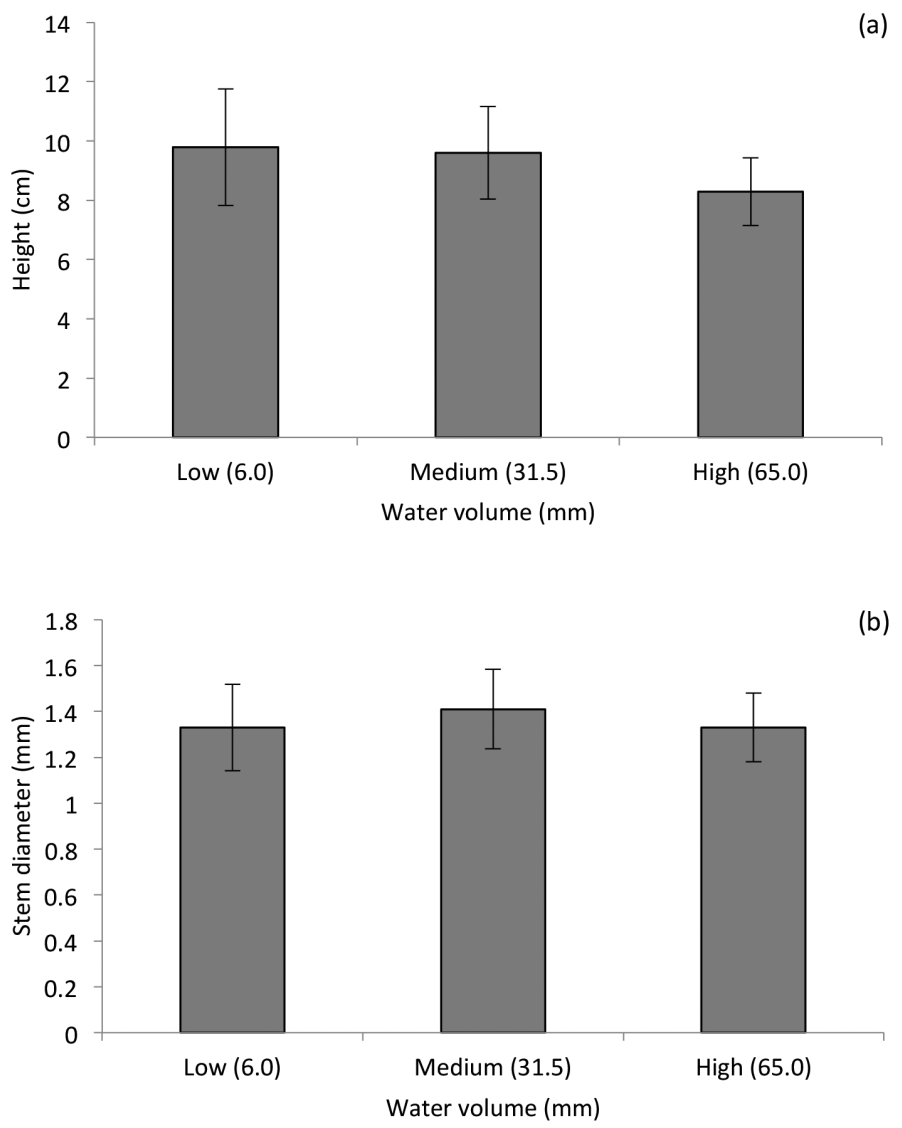

(b)

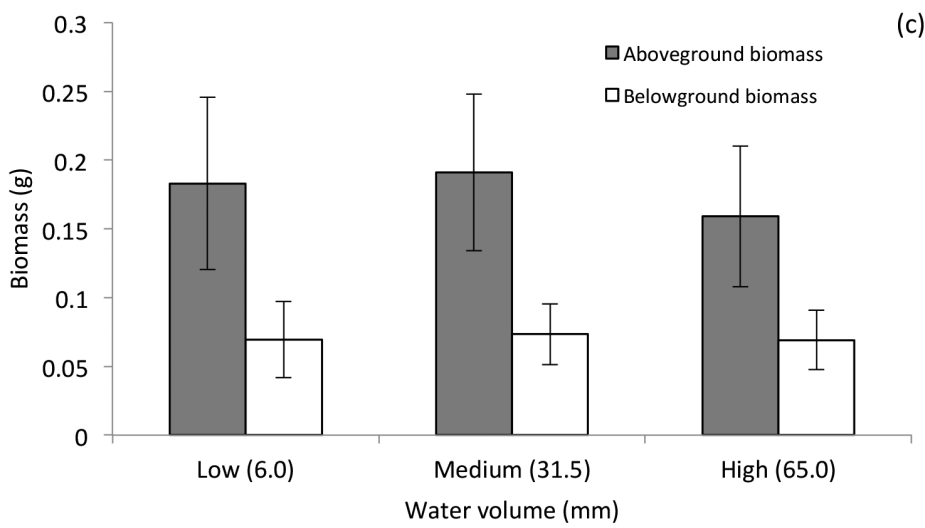

FIGURE 3. Morphological performances on (a) height and (b) stem diameter and (c) total biomass of $M$. pigra that received different volume of water per day 
grew from LW and HW treatments shared the same rate of diameter growth (Figure 3(b)). However, no significant difference $\left(\mathrm{F}_{2}, 18=0.139, p>0.05\right)$ in stem diameter was found across the treatments. Plants that received MW had the highest above-ground biomass, followed by seedlings grown in LW and HW conditions (Figure 3(c)). However, plants from all three different watering volumes had the same biomass of below-ground parts. Analysis indicates no significant effect of water volume on the biomass of either above- or below-ground plant parts across the levels of treatment $\left(\mathrm{F}_{2,27}=0.849, p>0.05\right.$ and $\mathrm{F}_{2,27}=0.096, p>0.05$, respectively).

This study suggested that the height of $M$. pigra progressively decreased as water received by the plant increased. This could be caused by excessive watering leaching away some soil nutrients (Luvaha et al. 2005). Although M.pigra is categorized as a semi-aquatic weed (Asyraf \& Crawley 2011), a high amount of water received by the plant per day could exceed the limit in its primary growth system (Robert 2008). This has been supported by studies on legume species (Kozlowski 1997; Striker et al. 2008). Such works have found that plant response to soil inundation was subjected to the inhibition or slowing of vegetative and reproductive growth (Striker et al. 2008). Meanwhile, Gimenez et al. (2005) reported that insufficient water will directly inhibit a plant from undergoing a photosynthesis process that eventually affects the whole growth system. However, in this experiment, as the plants received low water volume, the stems grew faster. These results were contrary to those of the studies from Gorai et al. (2010) and Shao et al. (2008), which suggested that water deficit caused height reduction in stressed plants. This may suggest that different species have different responses to water stress. In addition, Berman and Dejong (1997) stated that plant cell division has been found to be less sensitive to water deficit, enabling plants to continue their extensive growth and survive even under water-limited conditions as long as their water potential is in a state of equilibrium. However, the quantity and quality of plant productivity growth both depend on cell differentiation and enlargement. These processes, however, are directly affected by water deficit (Cabuslay et al. 2002). As plant photosynthesis rates are inhibited by water stress, limiting carbohydrate resources in plants reduces growth rates (Berman \& Dejong 1997; Kozlowski 1997). Thus, stem thickness is limited due to resource limitation allocation in plants. Blum (2011) stated that total biomass increases for plants that grow under conditions of water scarcity. The results in this study, however, may differ from many other studies of different species (Wang et al.2005), perhaps due to the reduction in total dry matter as a factor behind the decreasing photosynthesis process and plant growth related to the rate of primary and secondary growth (Lambers et al. 2008). Cell expansion is important for root expansion, particularly in drying soil, as water deficit normally reduces root growth more than shoot growth (Blum 2011). However, suppression of root development may have an adverse effect on the absorption of nutrients, affecting the comprehensive growth of the plant system (Kozlowski 1997).

\section{CONCLUSION}

This study suggested that a high species density habitat with strong intraspecific competition can cause the plant to grow vigorously upward with low chance of seedling survivability. Meanwhile, a habitat comprised of low species density and low intraspecific competition shows more sturdy plant growth, with a high seedling survivability rate in relation to the high density species habitat. Thus, competition has been shown to lead to a variety of plant performances (Lonsdale \& Abrecht 1989). Continuous intense artificial defoliation had significant detrimental effects on plant growth performance, survivability and flower bud productivity. However, with low and moderate tissue losses, plants have the chance to grow and reach the reproductive stage normally, even with low morphological growth compared with non-defoliated plants. This study also found that M.pigra is able to tolerate a specified level of water regime. A high water regime provides better growth conditions for M. pigra to develop well morphologically in comparison to other plants from different water regimes. None of the treated $M$. pigra demonstrated any mortality symptoms or performed inclining growth over the experiment and neither did they grow under a low or high level water regime. This makes $M$. pigra a tough woody semi-aquatic weed that is unlikely to be outgrown by native species of any given invaded habitat. Based on the results of this study, it may be concluded that plants respond in distinct ways to morphological aspects (i.e. height and diameter) and biomass allocation as well as the productivity of flower buds is relative to various simulated environmental gradients.

\section{ACKNOWLEDGEMENTS}

This research was financially supported by Grants FRGSKPT203/PBio/6711223 and 1001/PBIOLOGI/836004 (USM-RU-PRGS). We thank the School of Biological Sciences, Universiti Sains Malaysia for technical and logistic assistance. We wish to express our profound gratitude to our research members, academic and nonacademic staffs for their constant help, advice and encouragement since the commencement of this research and throughout the field work.

\section{REFERENCES}

Asyraf, M. \& Crawley, M. 2011. Current status of Mimosa pigra L. infestation in Peninsula Malaysia. Tropical Life Sciences Research 22(1): 41-55.

Ballare, C., Sanchez, R., Scopel, A. \& Ghersa, C. 1988. Morphological responses of Datura ferox L. seedlings to the presence of neighbours. Their relationships with canopy microclimate. Oecologia 76(1): 288-293. 
Baraza, E., Zamora, R., Hodar, J.A. \& Gomez, J.M. 2007. Plantherbivore interaction: Beyond a binary vision. In Functional Plant Ecology. 2nd ed., edited by Pugnaire, F.I. \& Valladares, F. New York: CRC Press. pp. 482-501.

Beilfuss, R. 2007. Adaptive Management of the Invasive Shrub Mimosa pigra at Gorongosa National Park. Gorongosa: Department of Scientific Services, Mozambique.

Berman, M.E. \& DeJong, T.M. 1997. Crop load and water stress effects on daily stem growth in peach (Prunus persica). Tree Physiology 17(7): 467-472.

Blum, A. 2011. Plant water relations, plant stress and plant production. In Plant Breeding for Water-limited Environments. New York: Springer. pp. 11-52.

Cabuslay, G.S., Ito, O.O. \& Alejal, A.A. 2002. Physiological evaluation of responses of rice (Oryza sativa L.) to water deficit. Plant Science 163(4): 815-827.

Fitter, A.H. \& Hay, R.K. 2002. Environmetal Physiology of Plants. 3rd ed. London: Academic Press.

Gimenez, C., Gallardo, M.\& Thompson, R.B. 2005. Plant-Water Relations. Oxford, UK: Elsevier.

Gorai, M., Hachef, A. \& Neffati, M. 2010. Differential responses in growth and water relationship of Medicago sativa (L.) cv. Gabes and Astragalus gombiformis (Pom.) under waterlimited conditions. Emirates Journal of Food and Agriculture 22(1): 1-12.

Hanley, M.E. \& Fegan, E.L. 2007. Timing of cotyledon damage affects growth and flowering in mature plants. Plant, Cell and Environment 30(7): 812-819.

Keddy, P.A. 1990. Competitive hierarchies and centrifugal organization in plant communities. In Perspective on Plant Competition, edited by Grace, J.J. \& Tilman, D. San Diego: Academic Press. pp. 266-290.

Koptur, S., Smith, C.L. \& Lawton, J.H. 1996. Effects of artificial defoliation on reproductive allocation in the common vetch, Vicia sativa (Fabaceae: Pailionoideae). American Journal of Botany 83(7): 886-889.

Kozlowski, T.T. 1997. Responses of woody plants to flooding and salinity. Tree Physiology 17(7): 1-29.

Lambers, H., Chapin, F.S. \& Pons, T.L. 2008. Plant Physiological Ecology. 2nd ed. New York: Springer.

Lonsdale, W.M. 1992. The biology of Mimosa pigra. In A Guide to the Management of Mimosa pigra, edited by Harley, K.L.S. Canberra: CSIRO. pp. 8-32.

Lonsdale, W.M. \& Abrecht, D.G. 1989. Seedling mortality in Mimosa pigra, an invasive tropical shrub. The Journal of Ecology 77(2): 371-385.

Lonsdale, W.M., Harley, K.L.S. \& Gillett, J.D. 1988. Seed bank dynamics in Mimosa pigra, an invasive tropical shrub. Journal of Applied Ecology 25(3): 963-976.

Luvaha, E., Netondo, G.W. \& Ouma, G. 2005. Effect of Water Deficit on the Growth of Mango (Mangifera indica) Rootstock Seedlings. Kenya: Department of Botany and Horticulture.

Malaysian Mateorological Department. 2012. Malaysian rainfall forecast 2011. http://www.met.gov.my/index. php?lang=english. Accessed on 12 January 2012.

Mandre, M. 2002. Stress concepts and plants. Forestry Studies 36: 9-16.

Manjeru, P., Madanzi, T., Makeredza, B., Nciizah, A. \& Sithole, M. 2007. Effects of water stress at different growth stages on coponents and grain yield of common bean (Phaseolus vulgaris L.). African Crop Science Conference Proceedings 8: 299-303.
Marko, M. 1999. Controlling invasion of the exotic shrub (Mimosa pigra) in tropical Australian wetlands. Restoration \& Reclamation Review 4(6): 1-10.

Miller, I.L. 2004. Uses for Mimosa pigra. In Research and Management of Mimosa pigra, edited by Julien, M., Flanagan, G., Heard, T., Hennecke, B., Paynter, Q. \& Wilson, C. Australia: CSIRO Entomology. pp. 63-67.

Myers, J.H. \& Bazely, D.R. 2003. Ecology and Control of Introduced Plants. UK: Press Syndicate of the University of Cambridge.

Nagashima, H. \& Hikosaka, K. 2011. Plants in a crowded stand regulate their height growth so as to maintain similar heights to neighbours even when they have potential advantages in height growth. Annals of Botany 108(1): 207-214.

Napompeth, B. 1983. Preliminary screening of insects for biological control of Mimosa pigra L. in Thailand. In Proceedings of an International Symposium, Mimosa pigra Management, edited by Robert, G.L. \& Habeck, D.H. Chiang Mai, Thailand. pp. 121-127.

Orcutt, D.M. \& Nilsen, E.T. 2000. Physiology of Plants Under Stress: Soil and Biotic Factors. Canada: John Wiley \& Sons.

Orwa, C., Mutua, A., Kindt, R., Jamnadass, R. \& Simons, A. 2009. Mimosa pigra L. Agroforestry Database 4.0 4(1): 1-5.

Pires, M.V., de Almeida, A.A.F., Figueiredo, A.L., Gomes, F.P. \& Souza, M.M. 2012. Germination and seedling growth of ornamental species of Passiflora under artificial shade. Acta Scientiarum. Agronomy 34(1): 67-75.

Praneetvatakul, S. 2001. An Impact Assessment of ACIAR Research Projects on Biological Control in Thailand. 38. Impact Assessments of forty-nine Thailand/Australia Collaborative Projects Funded by ACIAR during 1983-1995 Working Paper.

Quintero, C. \& Bowers, M.D. 2013. Effects of insect herbivory on induced chemical defences and compensation during early plant development in Penstemon virgatus. Annals of Botany 112(4): 1-9.

Richards, J.H. 1993. Physiology of plants recovering from defoliation. Proceedings of the XVII International Grassland Congress. Palmerston North, New Zealand: SIR Publishing. pp. 85-94.

Robert, S.H. 2008. A Dictionary of Biology. USA: Oxford University Press.

Sexton, J.P., McKay, J.K. \& Sala, A. 2002. Plasticity and genetic diversity may allow saltcedar to invade cold climates in North America. Ecological Applications 12(6): 1652-1660.

Shao, H.B., Chu, L.Y., Jaleel, C.A. \& Zhao, C.X. 2008. Waterdeficit stress-induced anatomical changes in higher plants. Comptes Rendus Biologies 331(3): 215-225.

Striker, G.G., Insausti, P. \& Grimoldi, A.A. 2008. Flooding effects on plants recovering from defoliation in Paspalum dilatatum and Lotus tenuis. Annals of Botany 102(2): 247-254.

Trewavas, A. 2009. What is plant behaviour?. Plant, Cell and Environment 32(6): 606-616.

Wang, F.Z., Wang, Q.B., Kwon, S.Y., Kwak, S.S. \& Su, W.A. 2005. Enhanced drought tolerance of transgenic rice plants expressing a pea manganese superoxide dismutase. Plant Physiology 162: 465-472.

Wirf, L.A. 2006. The effect of manual defoliation and Macaria pallidata (Geometridae) herbivory on Mimosa pigra: Implications for biological control. Biological Control 37(3): 346-353.

Yasari, E. \& Golafshan, M.G. 2012. Study of the spatial relationship between seed bank and weed populations and the 
distribution pattern of weeds in corn fields during the growing season. International Journal of Biology 4(4): 101-111.

School of Biological Sciences

Universiti Sains Malaysia

11800 Minden, Pulau Pinang

Malaysia
*Corresponding author; email: nurzhafarina@ymail.com

Received: 2 February 2016

Accepted: 3 February 2017 